\title{
Microbial activities accompanying decomposition of cladoceran and copepod carcasses under different environmental conditions
}

\author{
Kam W. Tang ${ }^{1, *}$, Samantha L. Bickel ${ }^{1}$, Claudia Dziallas ${ }^{2}$, Hans-Peter Grossart $^{2}$ \\ ${ }^{1}$ Virginia Institute of Marine Science, 1208 Greate Road, Gloucester Point, Virginia 23062, USA \\ ${ }^{2}$ Leibniz Institute of Freshwater Ecology and Inland Fisheries, Alte Fischerhuette 2, 16775 Stechlin, Germany
}

\begin{abstract}
Cladoceran and copepod carcasses in both marine and freshwater environments represent concentrated reservoirs of organic substrates for water column bacteria. We studied the microbial abundance, activities, and diversity associated with decomposing carcasses of different zooplankton species over short and long time scales, and in oligotrophic vs. eutrophic environments. Fresh carcasses of Daphnia cucullata, Diaphanosoma brachyurum, and Eudiaptomus gracilis were rapidly colonized by bacteria, which reached peak abundances within $1.5 \mathrm{~d}$ at $20^{\circ} \mathrm{C}$ and then decreased. Cell-specific exoenzymatic activity on protein and lipid analogs and production rate of bacteria associated with the carcasses were all higher than in the ambient water. ANOSIM analyses of DGGE banding patterns revealed that bacterial communities associated with both cladoceran and copepod carcasses rapidly diverged from the initial bacterial community in the ambient water. The high similarity of bacteria on both types of carcasses indicates that the carcasses were decomposed by similar bacterial groups. Estimated carcass decomposition rate was lower at $6^{\circ} \mathrm{C}$, with an estimated $\mathrm{Q}_{10}$ of 2.4. Carcasses suspended in the eutrophic Lake Dagow had a higher average carbon loss rate than those suspended in the oligotrophic Lake Stechlin. Cladoceran carcasses were initially colonized by bacteria faster than copepod carcasses in both laboratory and field experiments, suggesting that cladoceran carcasses were more prone to exploitation by bacteria, yet copepod carcasses lost carbon at higher rates. Overall, our results suggest that pelagic zooplankton production can be directly converted to water column bacterial production via carcass decomposition, especially during the mid-summer zooplankton decline commonly observed in lakes.
\end{abstract}

KEY WORDS: Decomposition - Exoenzymes - Bacterial production - Bacterial community composition · Zooplankton carcasses

\section{INTRODUCTION}

Conventional zooplankton ecology tends to ignore the existence of zooplankton carcasses in aquatic environments largely due to methodological difficulties in identifying and quantifying carcasses in natural samples. Despite these challenges, several studies have shown that zooplankton carcasses are sometimes prevalent in both marine and freshwater environments (Fig. 1). In a review of literature data, Hirst \& Kiørboe (2002) estimated that $1 / 4$ to $1 / 3$ of the total mortality of marine planktonic copepods can be attributed to non- predatory causes. In many lakes, Daphnia populations exhibit a mid-summer decline (Threlkeld 1979). Besides predation, it is almost certain that nonconsumptive factors, such as starvation and parasitism, contribute to this decline (Gries \& Güde 1999, Hülsmann \& Weiler 2000, Benndorf et al. 2001, Hülsmann \& Voigt 2002). Zooplankton carcasses resulting from nonconsumptive mortality could become an important organic source for water column bacteria, especially in oligotrophic waters (Grossart 1995).

Harding (1973) suggested that the decomposition of zooplankton carcasses is mainly driven by exogenous 


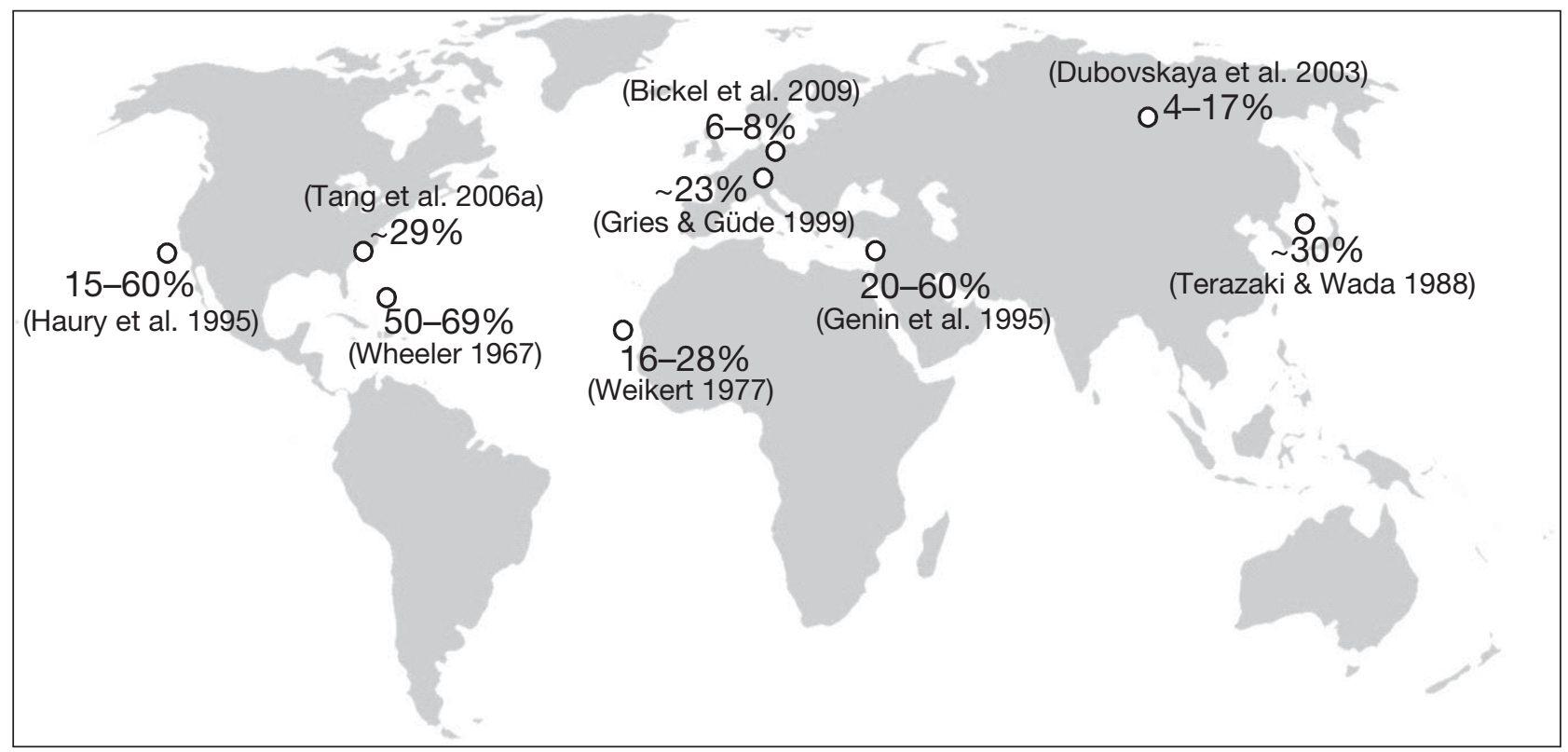

Fig. 1. Reported occurrences of dead zooplankton (as average \% of total zooplankton in samples). Data sources are provided in the reference list

bacteria (i.e. bacteria originating from the surrounding water) rather than endogenous bacteria, and recent studies have shown that zooplankton carcasses were rapidly colonized and decomposed by bacteria (Tang et al. 2006a,b). Microbial decomposition of zooplankton carcasses may provide an alternative but largely overlooked pathway for nutrient regeneration, elemental recycling and microbial production in the water column (Harding 1973, Lee \& Fisher 1992, Reinfelder et al. 1993). Tang et al. (2006b) showed that during the decomposition of the copepod Mesocyclops leuckarti, bacterial abundance and protease activity increased significantly in the surrounding water. Although data on carcass-associated bacteria were not available, the authors conservatively estimated that protease activity was enhanced by up to 6-fold inside the carcasses (Tang et al. 2006b). DGGE analysis of amplified 16S rRNA genes further showed a significant shift in the bacterial community composition during the decomposition process, indicating that certain types of bacteria were more adapted to exploit the resources associated with zooplankton carcasses (Tang et al. 2006b). Many zooplankton species occur in both eutrophic and oligotrophic systems where bacterial community structures and behaviors could be very different (Rath et al. 1993, Tang et al. 2006c); consequently, the fate of zooplankton carcasses and their effects on the ambient bacterial community may also differ between these systems.

Building upon our earlier work, we conducted laboratory and field studies to characterize the microbial processes associated with decomposing zooplankton carcasses over short (hours) and long (days) time scales. In the laboratory, we quantified the bacterial abundance, exoenzymatic activities and production associated with carcasses of different zooplankton species and in the surrounding water. We also examined the changes in bacterial community composition during the decomposition process. Furthermore, we conducted field experiments to investigate the carcass decomposition process in a eutrophic lake and in an oligotrophic lake. This information will improve our understanding of the contribution of different types of zooplankton carcasses to water column microbial activities under contrasting environmental conditions.

\section{MATERIALS AND METHODS}

Sampling sites. The study was conducted in August 2007. Zooplankton and epilimnion water were collected from Lake Stechlin $\left(53^{\circ} 09^{\prime} 03^{\prime \prime} \mathrm{N}, 13^{\circ} 01^{\prime} 40^{\prime \prime} \mathrm{E}\right)$

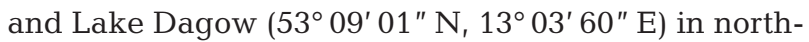
eastern Germany. Although Lake Dagow is connected to Lake Stechlin via a small outflow, the 2 lakes are very different in their nutrient status (Table 1): Lake Stechlin is a deep, oligotrophic lake (Casper 1996, Allgaier \& Grossart 2006) whereas Lake Dagow is a shallow, eutrophic lake (Casper 1996, Glissman et al. 2004) with seasonal hypoxic events (Gonsiorczyk et al. 1998). Both lakes exhibit thermal stratification in summer. At the time of the study, surface temperatures were $21 \pm 1^{\circ} \mathrm{C}$. 
Table 1. Hydrologic conditions of Lake Stechlin and Lake Dagow at the time of sampling

\begin{tabular}{|lcccc|}
\hline & Secchi depth $(\mathrm{m})$ & $\mathrm{NH}_{4}-\mathrm{N}\left(\mathrm{mg} \mathrm{l}^{-1}\right)$ & $\mathrm{PO}_{4}-\mathrm{P}\left(\mathrm{mg} \mathrm{l}^{-1}\right)$ & ${\mathrm{Chl} a\left(\mathrm{mg} \mathrm{l}^{-1}\right)}$ \\
\hline Lake Stechlin & 8 & 0.007 & 0.006 & 0.002 \\
Lake Dagow & 1.5 & 2.059 & 0.193 & 0.004 \\
\hline
\end{tabular}

Short-term laboratory experiment. Individuals of the cladoceran species Daphnia cucullata $(\sim 1.7 \mathrm{~mm})$ and the copepod species Eudiaptomus gracilis $(\sim 1.5 \mathrm{~mm})$ were collected from Lake Stechlin for the short-term experiment. Both were the numerically dominant species at the time of the study. Live individuals were gently concentrated on a nylon mesh, killed by brief exposure (a few seconds) to $10 \%$ acetic acid, and then immediately rinsed with $5 \mu \mathrm{m}$ filtered Lake Stechlin water to fully remove the acid. These carcasses were then transferred to sterile containers, each with $40 \mathrm{ml}$ of $5 \mu \mathrm{m}$ filtered lake water (20 carcasses per container; 12 containers per species). The water was pre-filtered through a $5 \mu \mathrm{m}$ sieve to retain natural bacterial assemblages while removing larger organisms that might prey on the bacteria or the carcasses; however, this filtration could not remove small bacterivorous protozoans (see discussion). Additional carcasses were collected at the beginning of the experiments for initial measurements of bacterial abundance, production, community composition, and exoenzymatic activities. The containers with carcasses were incubated on a shaker in the dark at $20 \pm$ $1^{\circ} \mathrm{C}$. At $6,12,24$ and 36 h, 3 containers from each species were sacrificed for the measurement of carcassassociated bacterial abundance, production, community composition, and exoenzymatic activities.

Long-term laboratory experiment. Daphnia cucullata, Eudiaptomus gracilis and Diaphanosoma brachyurum $(\sim 1 \mathrm{~mm})$ from Lake Stechlin were chosen for the long-term experiment for the same reason as in the short-term experiment. Fresh carcasses were prepared as described previously and transferred to sterile containers, each with $80 \mathrm{ml}$ of $5 \mu \mathrm{m}$ filtered lake water (40 carcasses per container; 9 containers per species). The containers were incubated on a shaker at $20 \pm 1^{\circ} \mathrm{C}$ in the dark. An additional set of containers with $D$. cucullata prepared in the same manner was incubated at $6^{\circ} \mathrm{C}$ to study the effect of temperature on the measured parameters. For controls, $5 \mu \mathrm{m}$ filtered lake water without carcasses was incubated in the same manner. Additional carcasses and water were collected for initial measurements of bacterial abundance, production, community composition, and exoenzymatic activities. Three containers from each species and the controls were sacrificed on Days 1.5, 3, and 7 for the measurement of carcass-associated and ambient bacterial abundance, production, community composition, and exoenzymatic activities.
Bacterial abundance, production and exoenzymatic activities. For carcass-associated bacterial abundance, 5 carcasses from each container were transferred into a glass tissue grinder. We took great care to minimize the amount of incidental surrounding water being included; nonetheless, a small amount of the ambient bacteria could have been transferred with the carcasses. Washing the carcasses in $0.2 \mu \mathrm{m}$ filtered lake water could have reduced the amount of incidental ambient bacteria, but that would have also caused a loss of carcass-associated bacteria, particularly during the later stages of the decomposition when the carcasses became very fragile. Darkfield microscopic observations (Tang et al. 2006a,b) confirmed that carcass-associated bacteria generally occurred in much higher concentrations than ambient bacteria; therefore, the error due to the small amount of water included should be relatively small. The carcasses were homogenized in $1 \mathrm{ml}$ of $0.2 \mu \mathrm{m}$ filtered lake water with a Teflon pestle, and the homogenate was filtered onto a $0.2 \mu \mathrm{m}$ black Nuclepore polycarbonate membrane. The pestle and grinder were rinsed twice with $0.2 \mu \mathrm{m}$ filtered lake water onto the same filter. SYBR Gold $(10 \mu \mathrm{l}$ stock in $141 \mu \mathrm{l}$ Moviol including $1 \mu$ ascorbic acid) was applied directly onto the filter, and the bacteria were counted under an epifluorescence microscope (Lunau et al. 2005). SYBR Gold was preferred for carcass-associated bacteria because it gave an intense fluorescence signal of the bacteria against the copepod detritus in the background. For ambient bacteria, $1 \mathrm{ml}$ of the surrounding water was filtered and stained with DAPI before counting under an epifluorescence microscope (Porter \& Feig 1980)

Rates of bacterial protein production (BPP) were determined using bacterial incorporation of ${ }^{14} \mathrm{C}$ leucine $\left({ }^{14} \mathrm{C}\right.$-Leu) according to Simon \& Azam (1989). Five carcasses from each container were homogenized with a tissue grinder in $5 \mathrm{ml}$ of $0.2 \mu \mathrm{m}$ filtered lake water; a $3 \mathrm{ml}$ aliquot of the bacterial suspension was transferred to a vial. Replicate vials and a formalinkilled control were incubated at the experimental temperatures in the dark for $1 \mathrm{~h}$ with ${ }^{14} \mathrm{C}$-Leu $(312 \mathrm{mCi}$ $\mathrm{mmol}^{-1}$, Amersham) at a final concentration of $50 \mathrm{nmol}$ $\mathrm{l}^{-1}$. This concentration ensured saturation of uptake systems of both ambient and carcass-associated bacteria based on pre-determined uptake kinetics. Samples were radio-assayed in a scintillation counter (Beck- 
man) and measured disintegrations per minute (DPM) were converted into ${ }^{14} \mathrm{C}$-Leu uptake and then into protein production according to Simon \& Azam (1989). To further convert protein production into carbon production, a conversion factor of 0.86 was used (Simon \& Azam 1989). Standard deviation of triplicate measurements was usually $\leq 15 \%$. Measured BPP was normalized to the bacterial abundance of the corresponding replicate to obtain cell-specific BPP.

Extracellular protease and lipase activities were respectively estimated from the hydrolysis of the fluorogenic protein analog L-leucine-methyl coumarinyl amide (Leu-MCA) (Hoppe 1983) and the lipid analog 4-methylumbelliferyl heptanoate (MUF-Hep) (Williams \& Jochem 2006). Because this method requires the addition of saturating concentrations of artificial substrates, the measurements represented the potential rather than the actual enzymatic activities. Enzymatic activity of ambient bacteria was measured from aliquots of incubation water from each of the containers. Three to 5 carcasses from each container were homogenized to determine either Leu-MCA or MUFHep hydrolysis by carcass-associated bacteria. Controls were prepared for each time point by adding formalin to additional aliquots or homogenates to stop the enzymatic activities. The aliquots or homogenates were incubated with $60 \mu \mathrm{l}$ of $5 \mathrm{mM}$ stock solution of Leu-MCA or MUF-Hep (0.1 mM final concentration) in the dark for $1 \mathrm{~h}$ at the experimental temperatures $\left(20\right.$ or $\left.6^{\circ} \mathrm{C}\right)$. Fluorescence was measured on a fluorometer (Kontron) at $380 \mathrm{~nm}$ excitation/440 nm emission for Leu-MCA, and $365 \mathrm{~nm}$ excitation/445 nm emission for MUF-Hep. Calibration curves were prepared by measuring the fluorescence over a range of MCA and MUF standard concentrations. Rates of Leu-MCA and MUF-Hep hydrolysis were normalized to the bacterial counts of the corresponding replicate to determine cell-specific rates.

Data were analyzed for significant effects due to time and treatments using ANCOVA. In cases where the requirement of normal distribution was not met, data were natural log-transformed prior to ANCOVA. Level of significance was set at $p=0.05$.

DGGE analysis. For carcass-associated bacteria, 10 carcasses from 1 of the replicates were transferred into a sterile $2 \mathrm{ml}$ Eppendorf vial and stored at $-20^{\circ} \mathrm{C}$ until DNA extraction. For ambient bacteria, a $5 \mathrm{ml}$ aliquot of water from the same replicate was filtered onto a $0.2 \mu \mathrm{m}$ polycarbonate filter and stored in the same manner until extraction. Bacterial DNA was extracted using the MoBio PowerSoil DNA isolation kit following the manufacturer's instruction. 16S rRNA gene fragments of bacteria were amplified using the universal primers 341f-GC and 907r (Muyzer \& Ramsing 1995). An equal amount of DNA ( $500 \mathrm{ng}$ ) was loaded in each lane and the denaturing gradient ranged from 40 to $70 \%$ (urea/formamide) in a $7 \%$ polyacrylamide gel. Running time of DGGE gels was $20 \mathrm{~h}$. Thereafter, DGGE gels were stained with SYBRGold (Molecular Probes) for $30 \mathrm{~min}$, destained with Milli-Q water for 10 min and illuminated on a UV table (Biometra). To test for significant differences in DGGE banding patterns between groups of samples, ANOSIM (Clarke \& Green 1988) was applied using the software PRIMER 6 version 6.1.9 (PRIMER-E). We compared bacterial DGGE banding patterns of attached and free-living bacteria between treatments with different copepod species and between different time points separately. ANOSIM generated a test statistic (R) which indicated the degree of separation between groups. A score of 1 indicated complete separation whereas a score of 0 indicated no separation. Further, a significance level was calculated based on maximally 999 (or all possible) permutations of the data set. We used the similarity matrix based on the dice similarity index calculated from the presence/absence of DGGE bands by using the software GelCompare II version 3.5 (Applied Maths) and UPGMA. The global value referred to the entire data set, and subsets were compared using pairwise comparisons.

Lake Stechlin and Lake Dagow field experiments. For the Lake Stechlin field experiment, fresh carcasses of Daphnia cucullata and Eudiaptomus gracilis were prepared as described above, and transferred to $73 \mathrm{ml}$ glass containers filled with $44 \mu \mathrm{m}$ filtered Lake Stechlin water (50 carcasses per container; 6 containers per species). Additional carcasses were collected for initial measurements of bacterial abundance and production, and carcass carbon and nitrogen contents (see below). The cap closure of the glass containers had a $25 \times 25 \mathrm{~mm}^{2}, 44 \mu \mathrm{m}$ nylon screen that allowed exchange of materials between the containers and the lake. The glass containers were suspended in the epilimnion of Lake Stechlin (3 $\mathrm{m}$ depth). On Days 1 and 2, 3 containers for each species were sacrificed for the measurement of carcass-associated bacterial abundance, BPP, and carcass carbon and nitrogen contents. For carcass carbon and nitrogen contents, 29 to 30 carcasses from each container were transferred to a tin capsule, freeze-dried immediately, and stored at room temperature until used. Blank capsules with a small drop of water from the container were included to correct for background carbon and nitrogen. Organic carbon and nitrogen contents of the carcasses were measured on an autoanalyzer (Carlo-Erba EA 1108; detection limits: $0.003 \mathrm{mg} \mathrm{C}, 0.00035 \mathrm{mg} \mathrm{N}$ ). For comparison, we conducted a second field experiment in eutrophic Lake Dagow. The experimental set-up was the same as in the Lake Stechlin field experiment. 


\section{RESULTS}

\section{Laboratory experiments}

ANCOVA results for the laboratory experiments are summarized in Table 2. In the short-term laboratory experiment, carcass-associated bacterial abundance increased markedly after $12 \mathrm{~h}$, and was significantly higher and more variable for Daphnia cucullata than for Eudiaptomus gracilis (Fig. 2A, Table 2). The BPP of carcass-associated bacteria was initially very low and increased significantly over time, but was not significantly different between zooplankton species (Fig. 2B, Table 2). Cell-specific protease activity was significantly higher in D. cucullata than in E. gracilis carcasses, and decreased significantly with time in both treatments (Fig. 2C, Table 2). Dice similarity of DGGE banding patterns revealed that bacterial communities associated with carcasses of E. gracilis and D. cucullata dramatically changed after $1 \mathrm{~d}$ of incubation (data not shown). There was no significant difference in the bacterial communities between the studied carcass types (data not shown), indicating that similar bacteria rapidly grew on both E. gracilis and D. cucullata carcasses.

In the long-term experiment, carcass-associated bacterial abundance changed significantly with time, and peaked after $1.5 \mathrm{~d}$ at $20^{\circ} \mathrm{C}$ (Fig. 3A, Table 2), although the differences among zooplankton species were not significant (Table 2). These peaks coincided with peaks in ambient bacterial abundances (Fig. 3B). During this time, BPP was greatly enhanced in the carcass treatments relative to the control (Fig. 4A), but was not significantly different among zooplankton species (Table 2). In the $6^{\circ} \mathrm{C}$ treatment, carcass-associated bacterial abundance and BPP increased more slowly and peaked at lower levels relative to the $20^{\circ} \mathrm{C}$ treatment (Figs. 3A $\& 4 \mathrm{~B})$; ambient bacterial abundances remained rather steady until Day 3, and increased to $>10^{7}$ bacteria $\mathrm{ml}^{-1}$ by Day 7 in both treatment and control groups (Fig. 3B). Carcass-associated cell-specific protease and lipase activities increased significantly over time (Table 2) and became highly variable toward the end of the experiment (Fig. 5A,C), although there were no significant differences among zooplankton species, or between 20 and $6^{\circ} \mathrm{C}$ for the Daphnia cucullata treatment. In the am-

Table 2. Summary of ANCOVA results. BPP: Bacterial protein production

\begin{tabular}{|c|c|c|c|c|c|c|c|}
\hline Experiment & Sample type & Treatment & Dependent variable & $F_{\text {treatment }}$ & $\mathrm{p}_{\text {treatment }}$ & $F_{\text {time }}$ & $\mathrm{p}_{\text {time }}$ \\
\hline \multirow{3}{*}{$\begin{array}{l}\text { Short-term } \\
\text { laboratory }\end{array}$} & \multirow[t]{3}{*}{ Carcasses } & \multirow[t]{3}{*}{ Zooplankton } & Bacterial abundance & 4.553 & 0.042 & 50.078 & 0.000 \\
\hline & & & Cell-specific BPP & 0.000 & 0.999 & 15.984 & 0.000 \\
\hline & & & Cell-specific protease activity & 7.097 & 0.013 & 34.296 & 0.000 \\
\hline \multirow{8}{*}{$\begin{array}{l}\text { Long-term } \\
\text { laboratory }\end{array}$} & \multirow[t]{4}{*}{ Carcasses at $20^{\circ} \mathrm{C}$} & \multirow[t]{4}{*}{ Zooplankton } & Bacterial abundance & 1.343 & 0.275 & 5.594 & 0.024 \\
\hline & & & Cell-specific BPP & 1.272 & 0.296 & 61.648 & 0.000 \\
\hline & & & Cell-specific protease activity & 0.406 & 0.671 & 38.655 & 0.000 \\
\hline & & & Cell-specific lipase activity & 0.255 & 0.777 & 47.135 & 0.000 \\
\hline & \multirow{4}{*}{$\begin{array}{l}\text { Ambient water at } \\
20^{\circ} \mathrm{C}\end{array}$} & \multirow[t]{4}{*}{ Zooplankton } & Bacterial abundance $^{\mathrm{a}}$ & 1.938 & 0.161 & 21.741 & 0.000 \\
\hline & & & Cell-specific BPP & 1.598 & 0.218 & 2.451 & 0.127 \\
\hline & & & Cell-specific protease activity & 1.161 & 0.326 & 9.800 & 0.004 \\
\hline & & & Cell-specific lipase activity & 2.227 & 0.124 & 28.426 & 0.000 \\
\hline \multirow{8}{*}{$\begin{array}{l}\text { Long-term } \\
\text { laboratory }\end{array}$} & \multirow{4}{*}{$\begin{array}{l}\text { Daphnia cucullata } \\
\text { carcasses }\end{array}$} & \multirow[t]{4}{*}{20 vs. $6^{\circ} \mathrm{C}$} & Bacterial abundance $^{\mathrm{a}}$ & 8.053 & 0.008 & 4.783 & 0.036 \\
\hline & & & Cell-specific BPP & 0.117 & 0.734 & 27.890 & 0.000 \\
\hline & & & Cell-specific protease activity & 0.793 & 0.381 & 21.139 & 0.000 \\
\hline & & & Cell-specific lipase activity & 0.831 & 0.370 & 19.102 & 0.000 \\
\hline & \multirow{4}{*}{$\begin{array}{l}\text { D. cucullata ambient } \\
\text { water }\end{array}$} & \multirow[t]{4}{*}{20 vs. $6^{\circ} \mathrm{C}$} & Bacterial abundance $^{\mathrm{a}}$ & 7.776 & 0.009 & 0.222 & 0.641 \\
\hline & & & Cell-specific BPP & 8.215 & 0.007 & 8.588 & 0.006 \\
\hline & & & Cell-specific protease activity & 8.501 & 0.007 & 7.133 & 0.012 \\
\hline & & & Cell-specific lipase activity & 4.464 & 0.043 & 8.194 & 0.008 \\
\hline \multirow{4}{*}{$\begin{array}{l}\text { Stechlin field } \\
\text { expt }\end{array}$} & \multirow[t]{4}{*}{ Carcasses } & \multirow[t]{4}{*}{ Zooplankton } & Bacterial abundance & 11.603 & 0.003 & 26.207 & 0.000 \\
\hline & & & Cell-specific BPP & 0.823 & 0.379 & 5.905 & 0.028 \\
\hline & & & Carcass carbon & 75.038 & 0.000 & 81.608 & 0.000 \\
\hline & & & Carcass nitrogen & 3.996 & 0.064 & 11.653 & 0.004 \\
\hline \multirow{4}{*}{$\begin{array}{l}\text { Dagow } \\
\text { field expt }\end{array}$} & \multirow[t]{4}{*}{ Carcasses } & \multirow[t]{4}{*}{ Zooplankton } & Bacterial abundance & 1.556 & 0.229 & 29.485 & 0.000 \\
\hline & & & Cell-specific BPP & 0.594 & 0.453 & 9.764 & 0.007 \\
\hline & & & Carcass carbon & 0.060 & 0.810 & 44.336 & 0.000 \\
\hline & & & Carcass nitrogen & 0.730 & 0.406 & 4.973 & 0.041 \\
\hline \multirow[t]{2}{*}{ Field expt } & \multirow{2}{*}{$\begin{array}{l}\text { Eudiaptomus gracilis } \\
\text { carcasses }\end{array}$} & \multirow{2}{*}{$\begin{array}{l}\text { Stechlin vs. } \\
\text { Dagow }\end{array}$} & Bacterial abundance & 16.299 & 0.001 & 49.935 & 0.000 \\
\hline & & & Carcass carbon & 18.183 & 0.001 & 65.219 & 0.000 \\
\hline
\end{tabular}



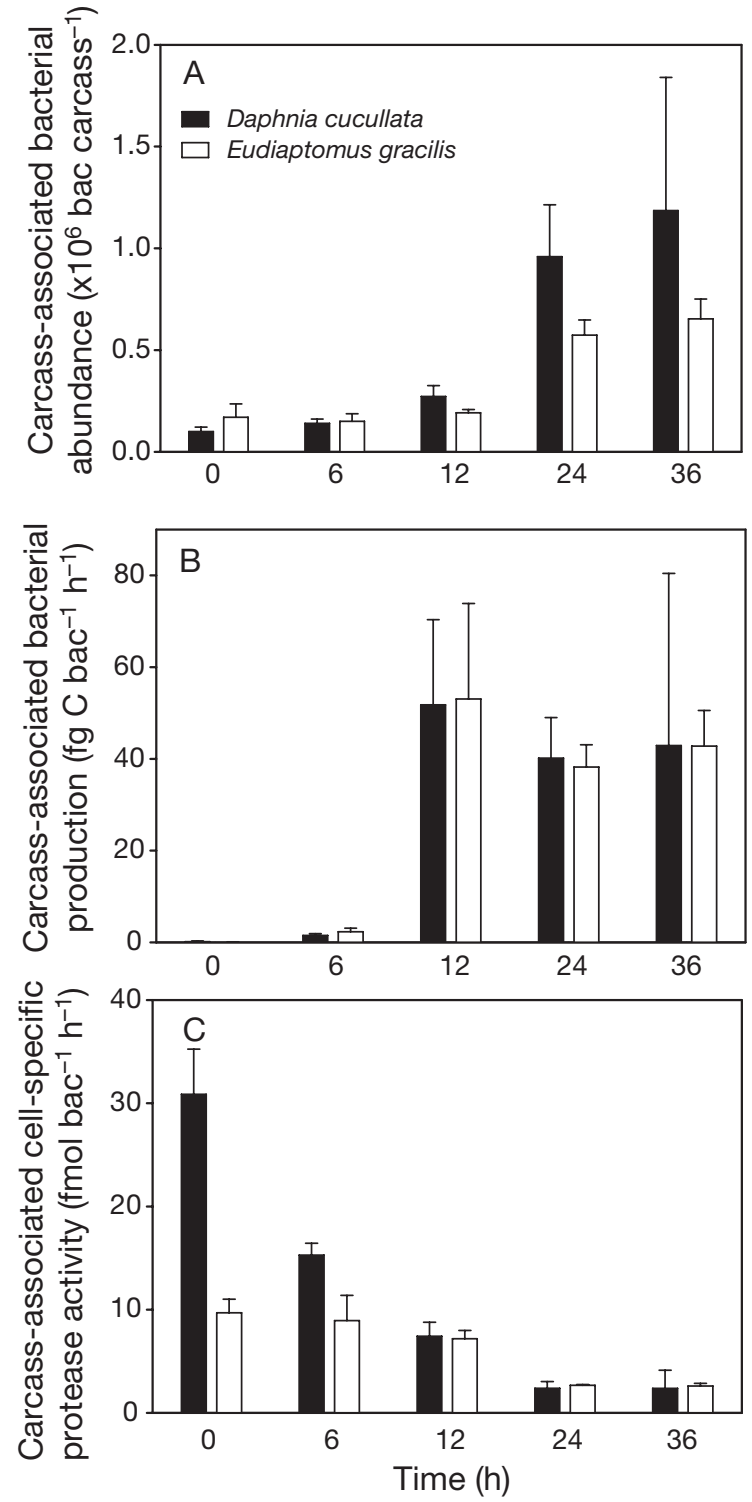

Fig. 2. Short-term laboratory experiment. Microbial activities (means + SDs) associated with zooplankton carcasses: (A) bacterial abundances; (B) cell-specific bacterial production; (C) cell-specific protease activity. ANCOVA results are provided in Table 2. Bac: bacterium

bient water, cell-specific protease and lipase activities also increased significantly over time (Table 2), but remained much lower than those associated with carcasses (Fig. 5B,D). The ambient cell-specific enzymatic activity for the $D$. cucullata treatment was significantly lower at 6 than at $20^{\circ} \mathrm{C}$ (Table 2).

We calculated enhancement factors for the cell-specific enzymatic activities and BPP by dividing the mean rate associated with the carcasses by that in the ambient water. At $20^{\circ} \mathrm{C}$, the enhancement factor for protease and lipase activities ranged between 1.1 to 7.3 , whereas it ranged between 2.2 to 28.9 at $6^{\circ} \mathrm{C}$ (Table 3).
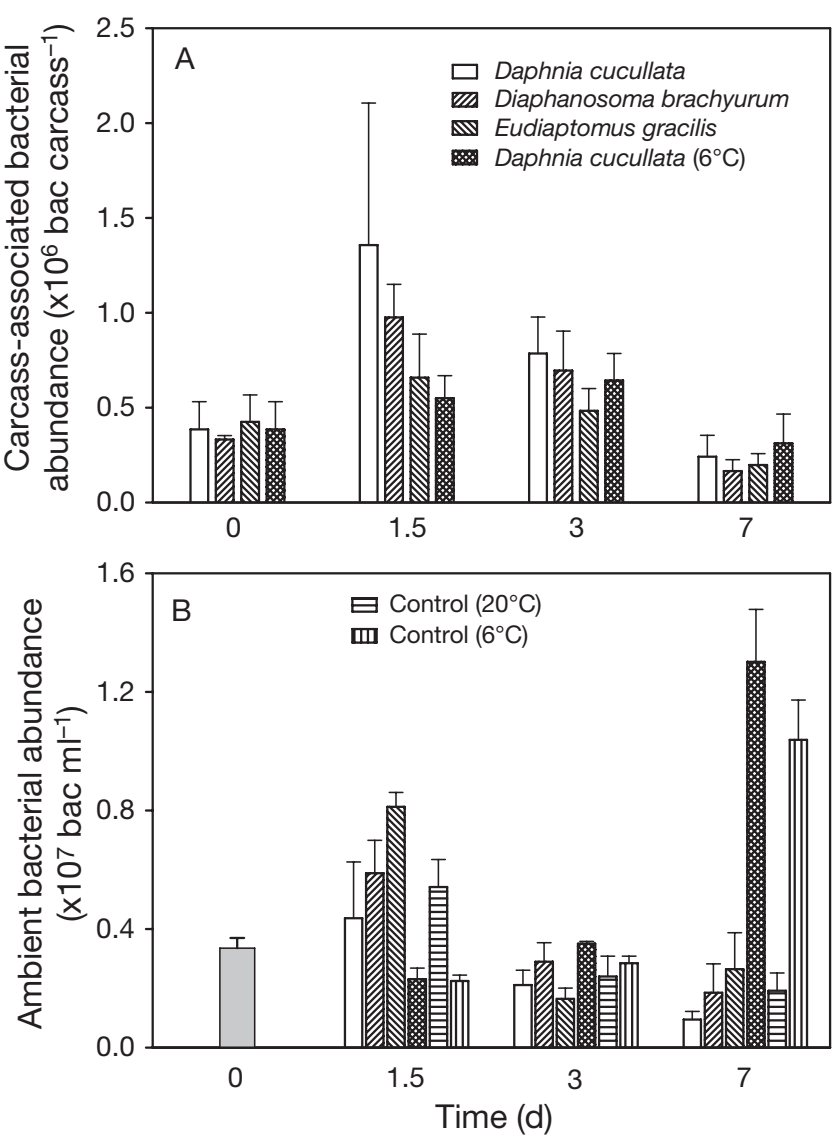

Fig. 3. Long-term laboratory experiment. Bacterial abundances (means + SDs) (A) associated with zooplankton carcasses and (B) in ambient water. There was only 1 set of measurements of ambient bacterial abundance at time 0 . ANCOVA results are provided in Table 2. Bac: bacterium

The enhancement factors for BPP were less than or close to 1 in the first $1.5 \mathrm{~d}$, and increased to as high as 11.0 at $20^{\circ} \mathrm{C}$ and 20.8 at $6^{\circ} \mathrm{C}$ (Table 3 ).

ANOSIM of DGGE banding patterns revealed that bacterial communities associated with carcasses were significantly different from those in the ambient water (Table 4). Bacterial communities on the carcasses significantly changed after $1 \mathrm{~d}$ of incubation (Table 4), indicating rapid growth of specific bacteria on all types of carcasses.

\section{Field experiments}

ANCOVA results for the field experiments are summarized in Table 2. Carcass-associated bacterial abundances increased significantly faster with Daphnia cucullata than with Eudiaptomus gracilis in Lake Stechlin (Fig. 6A, Table 2), but not in Lake Dagow (Fig. 6B, Table 2). Initial BPP rates of the carcass-associated bacteria were nearly undetectable in all cases; 

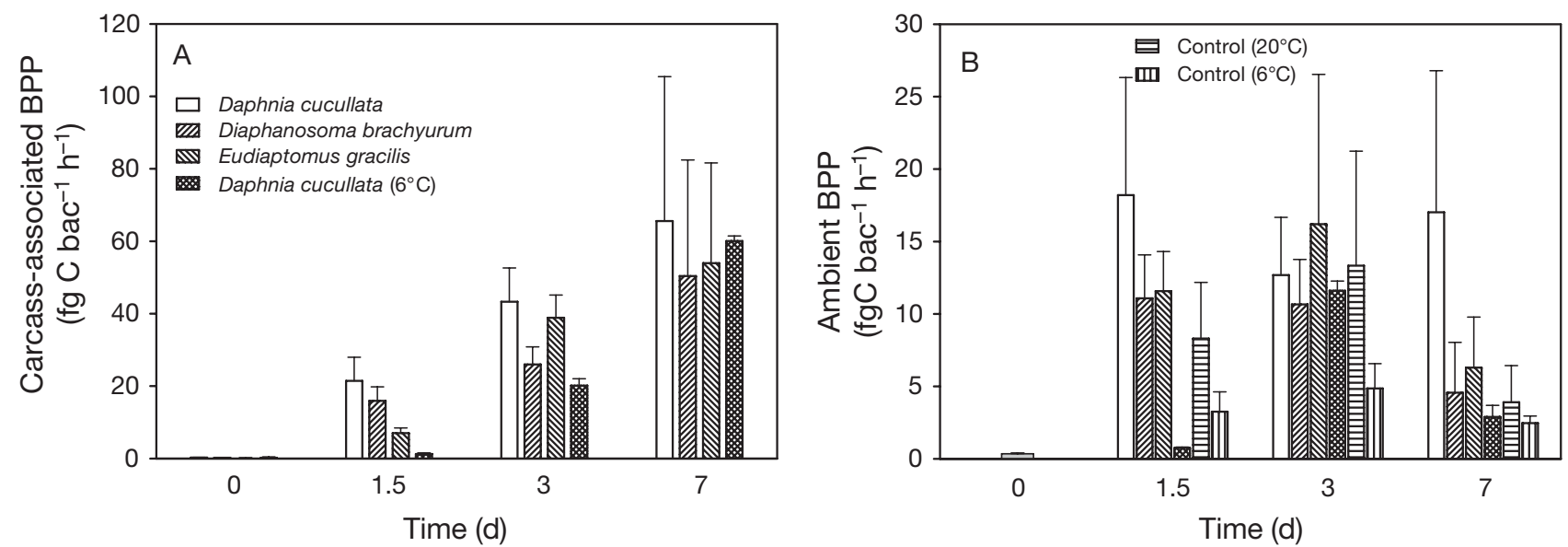

Fig. 4. Long-term laboratory experiment. Cell-specific bacterial protein production (BPP; means + SDs) (A) associated with zooplankton carcasses and (B) in ambient water. There was only 1 set of measurements of ambient BPP at time 0. ANCOVA results are provided in Table 2 . Bac: bacterium

by Day 1, BPP rates increased to $\sim 60 \mathrm{fg} \mathrm{C}$ bacterium $^{-1}$ $\mathrm{h}^{-1}$ in the $D$. cucullata treatment and $\sim 100 \mathrm{fg} \mathrm{C}$ bacterium $^{-1} \mathrm{~h}^{-1}$ in the E. gracilis treatment in both lakes

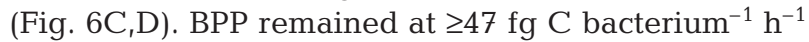
for both species in both lakes after $2 \mathrm{~d}$ (Fig. 6). There was no significant difference between zooplankton species in terms of BPP (Table 2).
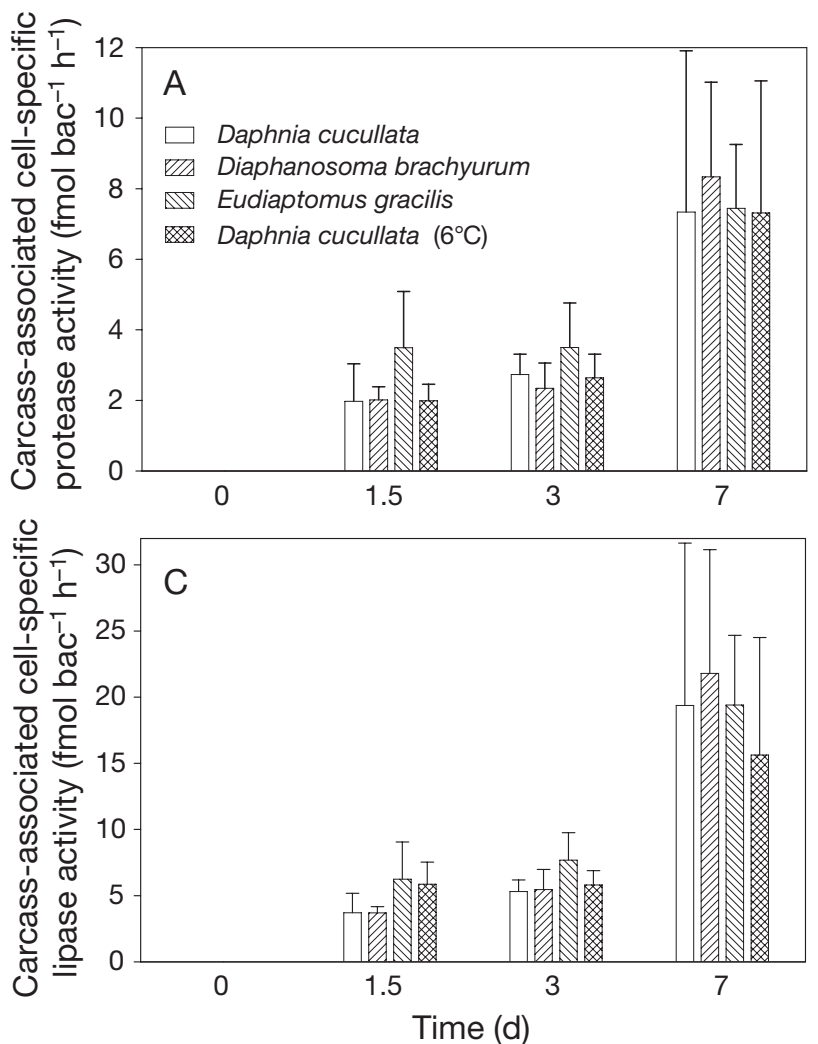

Carcass carbon and nitrogen contents decreased significantly over time in both field experiments (Fig. 7A,B, Table 2). In Lake Stechlin, the average loss rates over the $2 \mathrm{~d}$ incubation period for Daphnia cucullata carcasses were $0.42 \mu \mathrm{g} \mathrm{C} \mathrm{d}^{-1}$ and $0.05 \mu \mathrm{g} \mathrm{N} \mathrm{d}^{-1}$; the loss rate for Eudiaptomus gracilis carcasses was significantly higher for carbon $\left(0.52 \mu \mathrm{g} \mathrm{C} \mathrm{d}{ }^{-1}\right)$ but not for
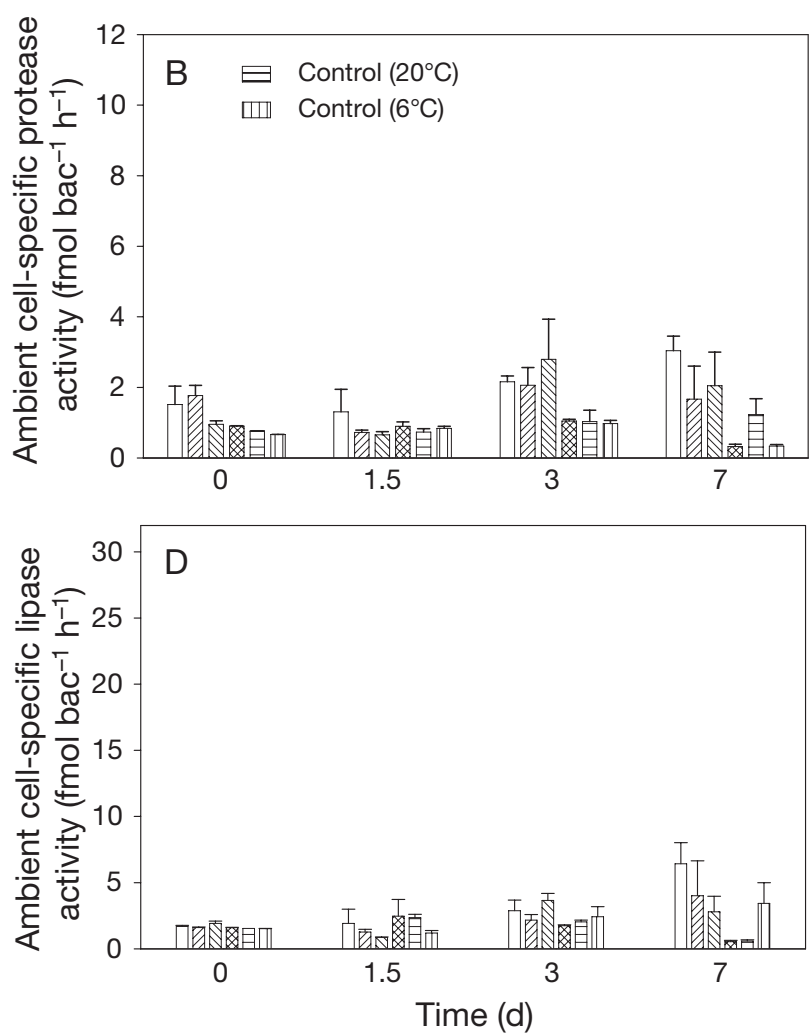

Fig. 5. Long-term laboratory experiment. Cell-specific protease and lipase activities (means + SDs) (A,C) associated with zooplankton carcasses and $(\mathrm{B}, \mathrm{D})$ in ambient water. ANCOVA results are provided in Table 2. Bac: bacterium 
Table 3. Enhancement factors (= rate associated with carcasses $\div$ rate in ambient water) for cell-specific protease and lipase activities and bacterial protein production (BPP) rates in the long-term laboratory experiment. Cell-specific enzymatic activities for Day 0 were not measured

\begin{tabular}{|c|c|c|c|c|}
\hline Day & Daphnia cucullata & Diaphanosoma brachyurum & Eudiaptomus gracilis & Daphnia cucullata $\left(6^{\circ} \mathrm{C}\right)$ \\
\hline \multicolumn{5}{|c|}{ Cell-specific protease activity } \\
\hline 1.5 & 1.51 & 2.78 & 5.33 & 2.22 \\
\hline 3 & 1.26 & 1.14 & 1.25 & 2.51 \\
\hline 7 & 2.41 & 5.01 & 3.64 & 22.53 \\
\hline \multicolumn{5}{|c|}{ Cell-specific lipase activity } \\
\hline 1.5 & 1.93 & 2.93 & 7.26 & 2.38 \\
\hline 3 & 1.84 & 2.52 & 2.01 & 3.31 \\
\hline 7 & 3.02 & 5.43 & 6.96 & 28.94 \\
\hline \multicolumn{5}{|c|}{ Cell-specific BPP } \\
\hline 0 & 0.80 & 0.77 & 0.51 & 0.66 \\
\hline 1.5 & 1.18 & 1.44 & 0.61 & 1.67 \\
\hline 3 & 3.41 & 2.44 & 2.40 & 1.73 \\
\hline 7 & 3.85 & 11.03 & 8.56 & 20.79 \\
\hline
\end{tabular}

Table 4. Results of ANOSIM for all samples of the long-term laboratory experiment. Similarities between attached and free-living bacteria, as well as between days, were calculated separately for all pairwise comparisons. \# $\geq$ observed: Number of permuted statistics $\geq$ global R

\begin{tabular}{|c|c|c|c|c|c|c|}
\hline Tested & Groups & $\mathrm{R}$ & $\mathrm{p}(\mathrm{R})$ & $\begin{array}{c}\text { Possible } \\
\text { permutations }\end{array}$ & $\begin{array}{c}\text { Actual } \\
\text { permutations }\end{array}$ & $\# \geq$ observed \\
\hline Attached/free- & Global & 0.341 & 0.001 & >99999999 & 999 & 0 \\
\hline living bacteria & Attached vs. free-living & 0.333 & 0.001 & >9999999 & 999 & 0 \\
\hline \multirow[t]{7}{*}{ Time (d) } & Global & 0.181 & 0.001 & >99999999 & 999 & 0 \\
\hline & 3 vs. 0 & 0.398 & 0.001 & 8008 & 999 & 0 \\
\hline & 3 vs. 7 & -0.040 & 0.720 & 92378 & 999 & 715 \\
\hline & 3 vs. 1 & -0.027 & 0.670 & 1144066 & 999 & 670 \\
\hline & 0 vs. 7 & 0.419 & 0.005 & 8008 & 999 & 4 \\
\hline & 0 vs. 1 & 0.663 & 0.001 & 27132 & 999 & 0 \\
\hline & 7 vs. 1 & 0.034 & 0.270 & 1144066 & 999 & 266 \\
\hline
\end{tabular}

nitrogen (0.09 $\mu \mathrm{g} \mathrm{N} \mathrm{d}^{-1}$; Table 2). In Lake Dagow, carcasses of D. cucullata lost $0.57 \mu \mathrm{g} \mathrm{C} \mathrm{d}^{-1}$ and $0.03 \mu \mathrm{g} \mathrm{N}$

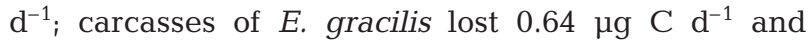
$0.09 \mu \mathrm{g} \mathrm{N} \mathrm{d}^{-1}$. No significant differences in carbon or nitrogen loss rates were detected between zooplankton species in Lake Dagow (Table 2). Comparison between lakes showed that E. gracilis carcasses lost carbon at a significantly higher rate in Lake Dagow (Table 2). When normalized to the initial values, the observed loss rates were equivalent to 26 to $43 \% \mathrm{C} \mathrm{d}^{-1}$ and 26 to $32 \% \mathrm{~N} \mathrm{~d}^{-1}$, or a half-life of 1.16 to $1.92 \mathrm{~d}$ in the 2 field experiments.

\section{DISCUSSION}

In the 2 laboratory experiments, carcass-associated bacterial abundance at $20^{\circ} \mathrm{C}$ peaked after $1.5 \mathrm{~d}$ and then decreased. This time trajectory is almost identical to our previous observations with other zooplankton species (Tang et al. 2006a,b). This recurring pattern indicates the existence of some mechanism(s) that regulate bacterial abundance. One possible mechanism is grazing by bacterivorous protozoans. Although the experimental water was pre-filtered through a $5 \mu \mathrm{m}$ filter, small bacterivorous protozoans could have passed through and entered the containers. Detrital aggregates have been shown to attract bacterivorous protozoans after the initial build-up of bacteria, the former grazing on the bacteria and altering bacterial community composition (Caron 1987, Ploug \& Grossart 2000, Kiørboe et al. 2004). Ciliates have also been observed to hover around naturally occurring copepod carcasses, presumably feeding on the bacteria (Tang et al. 2006b). Another possibility is viral lysis, which is also dependent on bacterial density (Wommack et al. 1992). Using the carcass-associated bacterial abundance data for the first $1.5 \mathrm{~d}$ (before substantial loss of bacteria to emigration or mortality) of the Daphnia cucullata treatments at 20 and $6^{\circ} \mathrm{C}$, we calculated a $\mathrm{Q}_{10}$ 

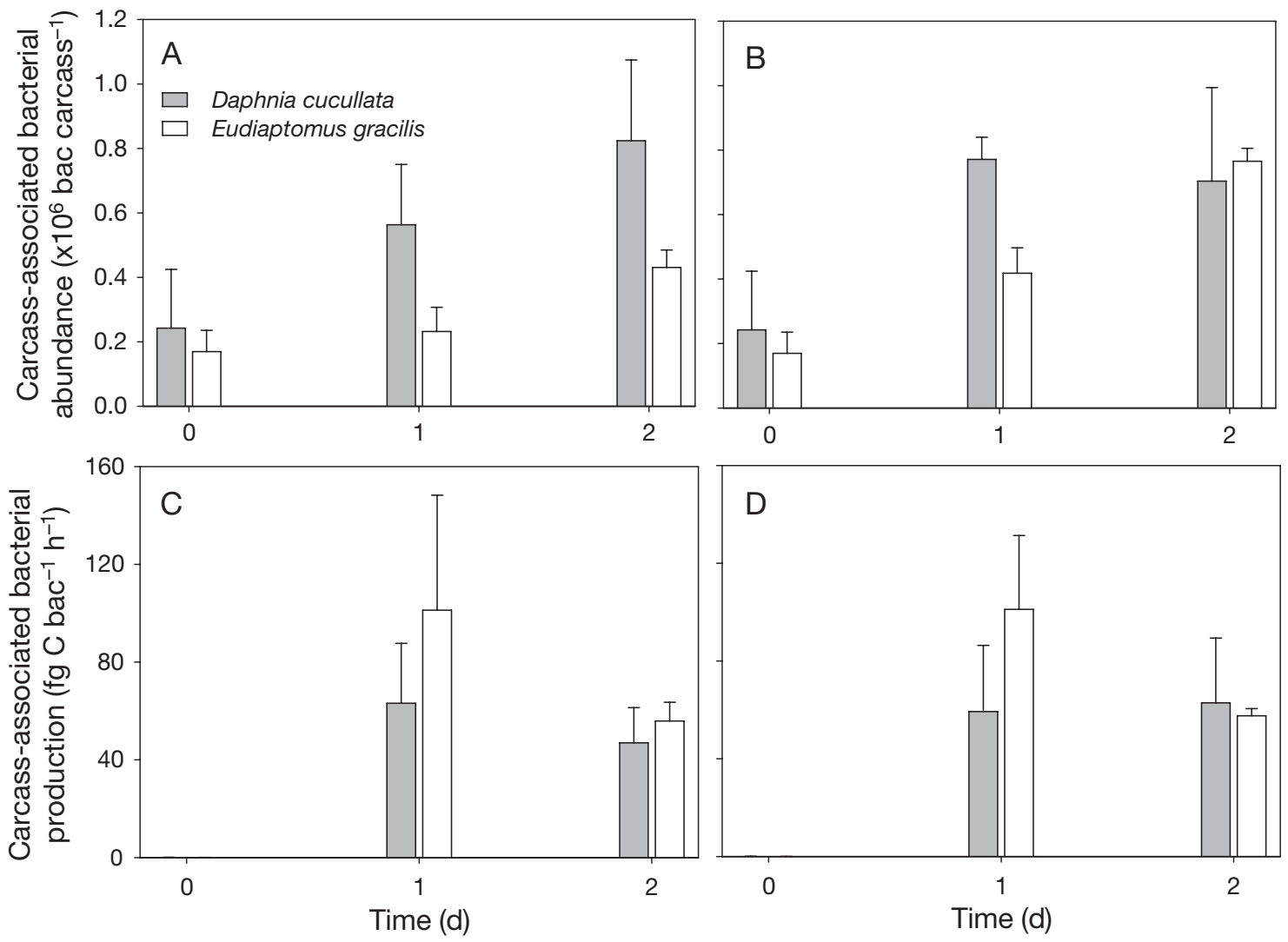

Fig. 6. Field experiments. Bacterial abundances associated with zooplankton carcasses suspended in (A) Lake Stechlin and (B) Lake Dagow; Cell-specific bacterial production associated with zooplankton carcasses suspended in (C) Lake Stechlin and (D Lake Dagow. Bacterial protein production was near 0 on Day 0. Data are shown as means + SDs. ANCOVA results are provided in Table 2. Bac: bacterium

of 2.4 for bacterial growth rate as a proxy for the decomposition process. This calculation should be regarded as an approximation of the true $Q_{10}$ because (1) only a fraction of the decomposed carcass biomass would have been converted to bacterial cell mass, and (2) an unknown fraction of the bacterial population could have been lost to emigration and mortality. Nonetheless, the calculated $\mathrm{Q}_{10}$ was within the common $Q_{10}$ values (1.2 to 4.8 ) for aquatic bacterial growth

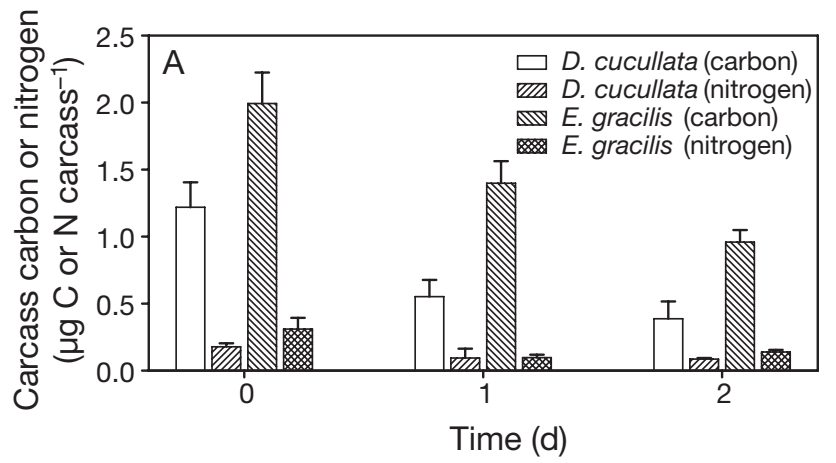

and production (Lovell \& Konopka 1985, Apple et al. 2006).

When we combined data from the 2 experiments, the overall trajectory of cell-specific enzymatic activities was a mirror image of that of bacterial abundances: it decreased markedly in the first $36 \mathrm{~h}$ and then increased again. This pattern may indicate the presence of 2 fractions of proteins and lipids within the carcasses: a more labile fraction that was quickly utilized

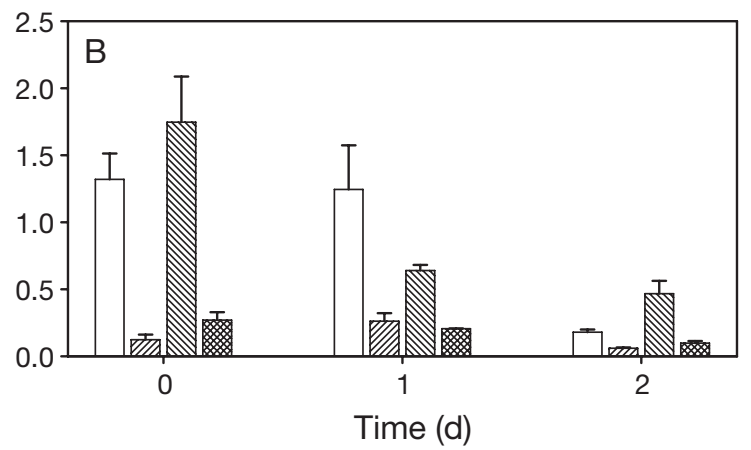

Fig. 7. Field experiments. Carbon and nitrogen contents (means + SDs) of zooplankton carcasses suspended in (A) Lake Stechlin and (B) Lake Dagow. ANCOVA results are provided in Table 2 
by bacteria initially, upon the depletion of which the enzymatic activity decreased; and a second, more refractory fraction that was slowly digested over a longer time, yielding a second phase of increase in the enzymatic activity. Reinfelder et al. (1993), who followed the decomposition of copepod carcasses at $15^{\circ} \mathrm{C}$, also identified 2 protein pools based on loss kinetics: a rapidly depleted pool with a half-life of $1.1 \mathrm{~d}$, and a slowly depleted pool with a half-life of $5.5 \mathrm{~d}$. Unfortunately, they did not have concurrent measurements of bacterial abundance or enzymatic activities. A future study combining measurements of bacterial abundance, enzymatic activities, and detailed analysis of protein and lipid compositions of the carcasses will be able to verify our suggestion.

The range of cell-specific protease activity was higher than the usual cell-specific protease activity for pelagic free-living bacteria, but comparable to that of bacteria attached to particles (Smith et al. 1995, Riemann et al. 2000, Grossart et al. 2007). Contrary to other studies, the observed cell-specific lipase activity in the present study was comparable to or slightly higher than that of protease, although their overall temporal trends and enhancement factors were similar. There are, however, examples of higher abundance and activity of lipolytic than of proteolytic bacteria in aquatic environments (Podgórska \& Mudryk 2003, Mudryk \& Skórczewski 2006). Indeed, it is commonly observed that a higher percentage of the total lipase activity than of total protease activity in lake water columns is due to extracellular enzymes produced by bacteria (Chróst \& Siuda 2002). Consistent with our earlier study (Tang et al. 2006b), we observed here that BPP and exoenzymatic activities were enhanced within the carcasses relative to the ambient water. More importantly, we showed that BPP and exoenzymatic activity associated with the carcasses were enhanced on a per cell basis; i.e. carcass-associated bacteria were more productive and enzymatically active than ambient bacteria.

The abundance of bacteria associated with cladoceran carcasses increased significantly faster than that of bacteria associated with copepod carcasses within the first $36 \mathrm{~h}$, although the difference between cladocerans and copepods dissipated over a longer time period. Cladoceran carcasses also showed a higher degree of fragmentation (visual observation). These results suggest that cladoceran carcasses were initially more prone to bacterial action than copepod carcasses, which were subsequently corroborated by our field experiments (see below). ANOSIM of DGGE banding patterns revealed that the zooplankton carcasses were rapidly colonized by specific bacteria. Based on cluster analysis using the Dice correlation index, ambient bacteria in the presence of zooplankton carcasses more closely resembled carcass-associated bacteria than bacteria in the controls, indicating the release of bacteria from decomposing carcasses to the surrounding water. Contrasting bacterial community compositions at 20 and $6^{\circ} \mathrm{C}$ indicate that environmental variables such as temperature were also crucial for the establishment of specific bacterial communities on the carcasses and in the ambient water.

In the field experiments, the carcass-associated bacterial abundances increased with time, but remained lower than those in the laboratory experiments after $2 \mathrm{~d}$. Because there was free water exchange between the containers and the lakes, loss of bacteria to emigration and predation was expected to be higher. The estimated half-lives for carcass carbon and nitrogen were comparable to those reported by Reinfelder et al. (1993) for proteins of marine copepod carcasses (average of $1.1 \mathrm{~d}$ at $15^{\circ} \mathrm{C}$ ). Using ${ }^{14} \mathrm{C}$-labeled copepod carcasses, Lee \& Fisher (1992) estimated a carbon loss rate of 11 to $22 \%$ over the first $2 \mathrm{~d}$. Our carbon loss rates were substantially higher, which may be because our incubation was conducted in a semi-open system, and small particulate matter might have been lost from the carcasses more readily. Lee \& Fisher (1992) also reported carbon leaching from the carcasses in the first $24 \mathrm{~h}$ even when microbial activity was inhibited by $\mathrm{HgCl}_{2}$, which is likely a result of autolysis within the tissues. However, this leached carbon appeared to be rapidly consumed when bacteria were present (Lee \& Fisher 1992). Autolysis of zooplankton upon death and the subsequent release of organic carbon is still largely an unexplored topic. Because ambient bacteria could respond to locally elevated dissolved organic carbon and colonize the source within minutes (Blackburn et al. 1998, Kiørboe et al. 2002), autolysis could play an important role in initiating bacterial colonization of the carcasses.

In Lake Stechlin, carcass-associated bacterial abundance increased faster in the Daphnia cucullata than in the Eudiaptomus gracilis treatment, indicating that the former was more prone to bacterial colonization, which is also consistent with our laboratory observations. Paradoxically, the carcass carbon loss rate was actually lower for D. cucullata, suggesting less efficient breakdown of its carcass by bacteria. On the other hand, BPP was not different between the 2 zooplankton species, meaning that bacteria were growing at similar rates within the 2 types of carcasses. Thus, the apparent inconsistency between the 2 species in the bacterial abundance data, the carbon data and the BPP data implies that (1) the bacteria associated with E. gracilis carcasses had larger cell sizes, or (2) there was a higher bacterial loss in the E. gracilis treatment. Cell size difference was not obvious in our samples. Although both zooplankton species were exposed to the same in situ 
condition, it is likely that emigration (passive or active) and mortality (predation or viral lysis) could differ between the species. This difference may also explain the uncoupling between the bacterial abundance data and the BPP data in the experiments. In Lake Dagow, carcass decomposition appeared to be less influenced by zooplankton species because no species-specific differences were detected in any of the decomposition parameters.

Comparison between lakes shows that Eudiaptomus gracilis carcasses were decomposed faster, in terms of changes in bacterial abundance and carbon content, in the eutrophic Lake Dagow than in the oligotrophic Lake Stechlin. This suggests that a higher ambient nutrient concentration would accelerate the decomposition of copepod carcasses, but its effect on Daphnia carcasses is less obvious. In addition to carbon, bacteria also require nitrogen and phosphorus for growth. The higher ambient concentrations of inorganic nitrogen and phosphorus in Lake Dagow might have allowed the bacteria to utilize copepod carcass carbon more effectively.

We observed in this and our previous studies that mainly the exoskeleton remained at the end of the decomposition. The exoskeleton of crustacean zooplankton is made up primarily of chitin. While chitinolytic bacterial activity is commonly found in lakes and estuaries (e.g. Kirchman \& White 1999, Brzezinska \& Donderski 2006), degradability of chitin in the natural environment depends on particle size, temperature and co-limiting factors (Hood \& Meyers 1977). In situ incubation of purified chitin particles usually showed a loss rate of $<1 \% \mathrm{~d}^{-1}$ (Hood \& Meyers 1977, Kirchner 1995, Kirchman \& White 1999). Indeed, chemical analysis of whole crustaceans showed that chitin was selectively preserved over $8 \mathrm{wk}$ (Baas et al. 1995). Massive die-off of crustaceans during the mid-summer decline, together with the low degradability of the exoskeleton, may inject a large amount of chitin to the bottom sediment where fungi and other microbes can remineralize the materials (LeCleir et al. 2004).

Cladocerans and copepods often dominate the zooplankton communities in freshwater and marine systems, and carcasses of both taxa have been observed in natural environments. The traditional view of zooplankton population dynamics tends to emphasize only mortality due to predation, whereas research into nonconsumptive mortality may lead not only to better understanding of the regulation of zooplankton populations, but also to new insights into microbial processes within the systems. Our results suggest that zooplankton production could be directly linked to bacterial production through nonconsumptive zooplankton mortality.
Acknowledgements. We thank K. Pohlmann for statistical analyses; P. Kasprzak for help with zooplankton species identification; and E. Mach, J. Dreyer and M. Lynch for technical assistance. The editor and 5 reviewers provided valuable comments. This study was supported by the U.S. National Science Foundation (OCE-0814558), the Jeffress Memorial Trust (J-895), the College of William \& Mary's Reves Graduate Student International Travel Grant, the German Science Foundation (DFG, GR1540/11-1), and the German Leibniz Foundation. This is contribution no. 3038 of the Virginia Institute of Marine Science.

\section{LITERATURE CITED}

Allgaier M, Grossart HP (2006) Diversity and seasonal dynamics of Actinobacteria populations in four lakes in northeastern Germany. Appl Environ Microbiol 72: 3489-3497

Apple JK, del Giorgio PA, Kemp WM (2006) Temperature regulation of bacterial production, respiration, and growth efficiency in a temperate salt-marsh estuary. Aquat Microb Ecol 43:243-254

Baas M, Briggs DEG, van Heemst JDH, Kear AJ, de Leeuw JW (1995) Selective preservation of chitin during the decay of shrimp. Geochim Cosmochim Acta 59:945-951

- Benndorf J, Kranich J, Mehner T, Wagner A (2001) Temperature impact on the midsummer decline of Daphnia galeata: an analysis of long-term data from the biomanipulated Bautzen Reservoir (Germany). Freshw Biol 46: 199-211

Bickel SL, Tang KW, Grossart H-P (2009) Use of aniline blue to distinguish live and dead crustacean zooplankton composition in freshwaters. Freshwater Biol 54:971-981

Blackburn N, Fenchel T, Mitchell J (1998) Microscale nutrient patches in planktonic habitats shown by chemotactic bacteria. Science 282:2254-2256

Brzezinska MS, Donderski W (2006) Chitinolytic bacteria in two lakes of different trophic status. Pol J Ecol 54:295-301

Caron DA (1987) Grazing of attached bacteria by heterotrophic microflagellates. Microb Ecol 13:203-218

Casper P (1996) Methane production in littoral and profundal sediments of an oligotrophic and a eutrophic lake. Arch Hydrobiol Beih Ergeb Limnol 48:253-259

Chróst RJ, Siuda W (2002) Ecology of microbial enzymes in lake ecosystems. In: Burns RG, Dick RP (eds) Enzymes in the environment: activity, ecology and applications. Chemical Rubber Company (CRC), New York, p 35-72

Clarke KR, Green RH (1988) Statistical design and analysis for a 'biological effects' study. Mar Ecol Prog Ser 46: $213-226$

Dubovskaya O, Gladyshev M, Gubanov VG, Makhutova ON (2003) Study of non-consumptive mortality of crustacean zooplankton in a Siberian reservoir using staining for live/dead sorting and sediment traps. Hydrobiologia 504: 223-227

> Genin A, Gal G, Haur L (1995) Copepod carcasses in the ocean. II. Near coral reefs. Mar Ecol Prog Ser 123:65-71

> Glissman K, Chin KJ, Casper P, Conrad R (2004) Methanogenic pathway and archaeal community structure in the sediment of eutrophic Lake Dagow: effect of temperature. Microb Ecol 48:389-399

Gonsiorczyk T, Casper P, Koschel R (1998) Phosphorus-binding forms in the sediment of an oligotrophic and an eutrophic hardwater lake of the Baltic Lake District (Germany). Water Sci Technol 37:51-58

Gries T, Güde H (1999) Estimates of the non-consumptive 
mortality of mesozooplankton by measurement of sedimentation losses. Limnol Oceanogr 44:459-465

Grossart HP (1995) Occurrence, formation and microbial processes on macroscopic organic aggregates (lake snow) and their relevance for nutrient turnover in Lake Constance. PhD thesis, University of Constance (in German)

- Grossart HP, Tang KW, Kiørboe T, Ploug H (2007) Comparison of cell-specific activity between free-living and attached bacteria using isolates and natural assemblages. FEMS Microbiol Lett 266:194-200

Harding GCH (1973) Decomposition of marine copepods. Limnol Oceanogr 18:670-673

Haury L, Fey C, Gal G, Hobday A, Genin A (1995) Copepod carcasses in the ocean. I. Over seamounts. Mar Ecol Prog Ser 123:57-63

> Hirst AG, Kiørboe T (2002) Mortality of marine planktonic copepods: global rates and patterns. Mar Ecol Prog Ser 230:195-209

Hood MA, Meyers SP (1977) Rates of chitin degradation in an estuarine environment. J Oceanogr Soc Jpn 33:328-334

- Hoppe HG (1983) Significance of exoenzymatic activities in the ecology of brackish water: measurements by means of methylumbelliferyl-substrates. Mar Ecol Prog Ser 11: 299-308

> Hülsmann S, Voigt H (2002) Life history of Daphnia galeata in a hypertrophic reservoir and consequences of non-consumptive mortality for the initiation of a midsummer decline. Freshw Biol 47:2313-2324

Hülsmann S, Weiler W (2000) Adult, not juvenile mortality as a major reason for the midsummer decline of a Daphnia population. J Plankton Res 22:151-168

Kiørboe T, Grossart HP, Ploug H, Tang K (2002) Mechanisms and rates of bacterial colonization of sinking aggregates. Appl Environ Microbiol 68:3996-4006

Kiørboe T, Grossart HP, Ploug H, Tang K, Auer B (2004) Particle-associated flagellates: swimming patterns, colonization rates, and grazing on attached bacteria. Aquat Microb Ecol 35:141-152

> Kirchman DL, White J (1999) Hydrolysis and mineralization of chitin in the Delaware Estuary. Aquat Microb Ecol 18: 187-196

Kirchner M (1995) Microbial colonization of copepod body surfaces and chitin degradation in the sea. Helgol Meeresunters 49:201-212

> LeCleir GR, Buchan A, Hollibough JT (2004) Chitinase gene sequences retrieved from diverse aquatic habitats reveal environment-specific distributions. Appl Environ Microbiol 70:6977-6983

Lee BG, Fisher NS (1992) Decomposition and release of elements from zooplankton debris. Mar Ecol Prog Ser 88: $117-128$

Lovell CR, Konopka A (1985) The effects of temperature on bacterial production in a dimictic eutrophic lake. FEMS Microbiol Ecol 31:135-140

Lunau M, Lemke A, Walther K, Martens-Habbena W, Simon M (2005) An improved method for counting bacteria from sediments and turbid environments by epifluorescence microscopy. Environ Microbiol 7:961-968

Mudryk ZJ, Skórczewski P (2006) Enzymatic activity and degradation of organic macromolecules by neustonic and

Editorial responsibility: Craig Carlson,

Santa Barbara, California, USA planktonic bacteria in an estuarine lake. Pol J Ecol 54: $3-14$

Muyzer G, Ramsing NB (1995) Molecular methods to study the organization of microbial communities. Water Sci Technol 32:1-9

Ploug H, Grossart HP (2000) Bacterial growth and grazing on diatom aggregates: respiratory carbon turnover as a function of aggregate size and sinking velocity. Limnol Oceanogr 45:1467-1475

Podgórska B, Mudryk ZJ (2003) Distribution and enzymatic activity of heterotrophic bacteria decomposing selected macromolecular compounds in a Baltic Sea sandy beach. Estuar Coast Shelf Sci 56:539-546

Porter KG, Feig YS (1980) The use of DAPI for identification and enumeration of bacteria and blue-green algae. Limnol Oceanogr 13:389-398

Rath J, Schiller C, Herndl GJ (1993) Ectoenzymatic activity and bacterial dynamics along a trophic gradient in the Caribbean Sea. Mar Ecol Prog Ser 102:89-96

> Reinfelder JR, Fisher NS, Fowler SW, Teyssié JL (1993) Release rates of trace elements and protein from decomposition of plankton debris. 2. Copepod carcasses and sediment trap particulate matter. J Mar Res 51:423-442

Riemann L, Steward GF, Azam F (2000) Dynamics of bacteria community composition and activity during a mesocosm diatom bloom. Appl Environ Microbiol 66:578-587

Simon M, Azam F (1989) Protein content and protein synthesis rates of planktonic marine bacteria. Mar Ecol Prog Ser 51:201-213

Smith DC, Steward GF, Long RA, Azam F (1995) Bacterial mediation of carbon fluxes during a diatom bloom in a mesocosm. Deep-Sea Res II 42:75-97

Tang KW, Freund CS, Schweitzer CL (2006a) Occurrence of copepod carcasses in the lower Chesapeake Bay and their decomposition by ambient microbes. Estuar Coast Shelf Sci 68:499-508

Tang KW, Hutalle KML, Grossart HP (2006b) Microbial abundance, composition and enzymatic activity during decomposition of copepod carcasses. Aquat Microb Ecol 45: 219-227

> Tang KW, Grossart HP, Yam EM, Jackson GA, Ducklow HW, Kiørboe T (2006c) Mesocosm study of particle dynamics and control of particle-associated bacteria by flagellate grazing. Mar Ecol Prog Ser 325:15-27

> Terazaki M, Wada M (1988) Occurrence of large numbers of carcasses of the large, grazing copepod Calanus cristatus from the Japan Sea. Mar Biol 97:177-183

> Threlkeld ST (1979) The midsummer dynamics of two Daphnia species in Wintergreen Lake, Michigan. Ecology 60: 165-179

Weikert H (1977) Copepod carcasses in the upwelling region south of Cap Blanc, N.W. Africa. Mar Biol 42:351-355

Wheeler EH (1967) Copepod detritus in the deep sea. Limnol Oceanogr 12:687-701

Williams CJ, Jochem FJ (2006) Ectoenzyme kinetics in Florida Bay: implications for bacterial carbon source and nutrient status. Hydrobiologia 569:113-127

Wommack KE, Hill RT, Kessel M, Russek-Cohen E, Colwell RR (1992) Distribution of viruses in the Chesapeake Bay. Appl Environ Microbiol 58:2965-2970

Submitted: June 25, 2008; Accepted: May 27, 2009

Proofs received from author(s): August 27, 2009 